\title{
PERANAN GURU PAI DALAM PEMELIHARAAN KEBERSIHAN DAN KESEHATAN DI SDN 23 SUNGAI TARAB KABUPATEN TANAHDATAR SUMBAR
}

\author{
Oleh: Asmendri*
}

\begin{abstract}
Abstrak
In general this study was aimed at 1) identifying the roles played by Islamic teaching (PAI) teachers as educators in integrating $P A I$ instructional materials into health education, 2) detecting $P A I$ teachers' participation in carrying out health services, and 3) identifying PAI teachers' roles as the supervisor of healthy school environment at SDN 23 Sungai Tarab. The findings show that the teachers were able to integrate PAI instructional materials into health programs conducted by the school. Such integration was especially carried out by means of topic on thabarah. In addition, the teachers took active participation in any health service program at the school. Though the percentage of their participation was not as significant as the classroom teachers, they kept participating in any school health programs carried out by the school.
\end{abstract}

Kata Kunci: guru, pemeliharaan, kebersihan, kesehatan

\section{PENDAHULUAN}

Dujuan Pengajaran PAI di SD/MI adalah membentuk peserta didik menjadi manusia yang beriman serta bertaqwa kepada Tuhan Yang Maha Esa serta berakhlak mulia. Untuk mencapai tujuan pengajaran tersebut guru PAI perlu mengacu kepada 6 Standar Kompetensi Kelompok Mata Pelajaran (SK-KMP) Agama dan Akhlak Mulia untuk SD/MI yang sesuai dengan acuan Permen Diknas No. 22 Tahun 2006. Yang menjadi masalah apakah PAI yang diselenggarakan di sekolah telah menyentuh dan menganggkat berbagai aspek kehidupan dan berperan dalam menanamkan nilai-nilai tersebut di sekolah atau malahan masih berputar pada penekanan aspek kesalehan ritual (ibadah mahdhoh), seperti solat dan puasa. Karena diantara 6 macam standar di atas, yang perlu mendapat perhatian khusus dan teraplikasi dengan baik oleh guru PAI adalah menunjukkan kebiasaan hidup bersih, sehat, bugar, aman dan memanfaatkan waktu luang sesuai dengan tuntunan agamanya. Apalagi konsep pertama yang diperhatikan dalam Islam adalah masalah kebersihan, penjelasannya dalam Surat Al Maidah ayat 6 dan surat Al-Mudatsir ayat 4. Di samping itu Nabi Muhammad SAW sangat menitik beratkan perhatiannya pada masalah kesehatan. Seharusnya dengan memperhatikan aspek-aspek tersebut lingkungan sekolah dan tempat ibadah akan selalu bersih dan nyaman.

Sekolah merupakan pusat pengembangan SDM, maka lingkungan di sekitarnya harus bersih dan sehat, untuk itu pula di setiap sekolah diselenggarakan program UKS. Program ini

* Penulis adalah Lektor dalam Mata Kuliah Manajemen Pendidikan pada STAIN Batusangkar 
menjadi tanggung jawab semua komponen yang ada di sekolah termasuk guru PAI. Namun kenyataannya jarang dijumpai sekolah atau madrasah yang terawat, ada taman yang rapi, bersih dan indah, sehingga siswanya menjadi menjadi betah berada disekolah tersebut. Melihat hal ini timbul pertanyaan bagaimama peran guru PAI? Mengapa guru PAI? Karena tugas utamanya membina akhlak di samping itu ia berperan sebagai pendukung program UKS di sekolahnya. Caranya dengan meintegrasikan materi PAI dengan program UKS dalam pembelajaran dan Perilaku seharihari. Bagaimana cara mengaplikasikannya dengan memberi contoh dan mengajak siswa membiasakan memelihara kebersihan dan kesehatan diri dan lingkungan sekolah. Karena dengan pembiasaan dan pengulangan maka perbuatan baik tersebut akan tumbuh dan berkembang secara wajar dalam diri peserta didiknya.

Hasil observasi pada beberapa sekolah yang ada di Kabupaten Tanahdatar, Propinsi Sumatera Barat, di Kabupaten ini ada satu sekolah yang berbeda dari sekolah lainnya, yaitu SDN 23 Sungai tarab di Kecamatan Sungai tarab. SD ini berhasil meraih juara 1 Lomba Sekolah Sehat (LSS) tingkat Kabupaten Tanahdatar tahun 2006 dan juara 1 tingkat Propinsi Sumatera Barat tahun 2007. Peneliti telah melaksanakan grandtour dengan fokus sekolah sehat di SD ini tanggal 23-24 Juli 2007. Hasilnya dapat dikemukakan sebagai berikut: (1) sekolah memiliki program kerja UKS, (2) lingkungan sekolah terlihat bersih, (3) ruangan kelas juga bersih, (4) penataan taman terlihat teratur, asri dan indah, (5) MCK terlihat bersih, (6) tidak terlihat sampah-sampah yang berserakan, (7) musholla terlihat bersih, begitu pun tempat wudhu', (8) punya tong sampah tiap kelas dan tempat parkir kenderaan yang teratur dan rapi, (9) punya ruangan UKS dan kolam sekolah, (10) ada ke- giatan ceramah kesehatan setiap hari Kamis, (11) punya Taman Obat Keluarga (TOGA) tapi tanaman terlihat kurang mencukupi, (12) pustaka belum berfungsi dengan baik, (13) kantin sekolah kurang luas, dan (14) belakang sekolah terlihat tidak tertata rapi.

Melihat keberhasilan ini berarti secara umum seluruh personil sekolah tersebut seperti kepala sekolah, guru, karyawan, petugas kebersihan dan lainlainnya telah berhasil dan berperan sekali dalam mewujudkan sekolah sehat. Namun Peneliti akan meneliti lebih khusus lagi di sekolah ini, tentang "Bagaimana Peranan Guru PAI di SDN 23 Sungai tarab tersebut dalam Pemeliharaan Kebersihan dan Kesehatan?" Karena masalah kebersihan dan kesehatan merupakan hal yang sangat penting dalam Islam dan bagaimana penerapannya dalam lingkungan sekolah dan sekitarnya. Ini merupakan upaya strategis untuk meningkatkan pemahaman peserta didik terhadap ajaran Islam.

Dengan demikian masalah yang diteliti dalam penelitian ini adalah berkenaan dengan peranan guru PAI dalam pemeliharaan kebersihan dan kesehatan. Peranan guru di sini difokuskan pada kompetensi dan keterampilan guru PAI sebagai pendidik, partisipan dan pembimbing dalam mengintegrasikan bahan ajar PAI pada proses pembelajaran dengan sistem pembinaan sekolah sehat yang berpedoman pada TRIAS UKS (pendidikan kesehatan, pelayanan kesehatan dan pembinaan ligkungan sehat).

Untuk mengidentifikasi lebih lanjut fokus penelitian ini perlu dirumuskan masalah penelitiannya, yaitu "Bagaimana peranan guru PAI sebagai pendidik, partisipan dan pembimbing dalam usaha pemeliharaan kebersihan dan kesehatan di SDN 23 Sungai tarab? 


\section{KAJIAN TEORETIK}

\section{Standar Kompetensi Mata Pelajaran PAI di Sekolah Dasar}

Sesuai dengan Peraturan Menteri Pendidikan Nasional (Permendiknas) RI No. 22 Tahun 2006 tentang Standar Isi Satuan Pendidikan Dasar dan Menengah yang menyatakan bahwa ada tiga Standar Kompetensi yang dijadikan acuan dalam pelaksanaan Kurikulum Tingkat Satuan Pendidikan (KTSP) di sekolah, yaitu (1) Standar Kompetensi Lulusan Satuan Pendidikan (SKL-SP), (2) Standar Kompetensi Kelompok Mata Pelajaran (SK-KMP), dan (3) Standar Kompetensi Lulusan Mata Pelajaran (SKLMP).

Di dalam Permendiknas ini juga dikemukakan SKL-SP untuk SD/MI/SDLB/Paket A yaitu: (1) menjalankan ajaran agama yang dianuta sesuai dengan tahap perkembangan anak, (2) mengenal kekurangan dan kelebihan diri sendiri, (3) mematuhi aturan-aturan sosial yang berlaku dalam lingkungannya, (4) menghargai keberagaman agama, budaya, suku, ras, dan golongan sosial ekonomi di lingkungan sekitarnya, (5) menggunakan informasi tentang lingkungan sekitar secara logis, kritis dan kreatif, (6) menunjukkan kemampuan berpikir logis, kritis, dan kreatif dengan bimbingan guru/pendidik, (7) menunjukkan rasa keingintahuan yang tinggi dan menyadari potensinya, (8) menunjukkan kemampuan memecahkan masalah sederhana dalam kehidupan sehari-hari, (9) menunjukkan kemampuan mengenali gejala alam dan sosial di lingkungan sosial, (10) menunjukkan kecintaan dan kepedulian terhadap lingkugan, (11) menunjukkan kecintaan dan kebanggaan terhadap bangsa, negara, dan tanah air Indonesia, (12) menunjukkan kemampuan untuk melakukan kegiatan seni dan budaya lokal, (13) menunjukkan kebiasaan hidup bersih, sehat, bugar, aman, dan memanfaatkan waktu luang, (14) berkomunikasi secara jelas dan santun, (15) bekerjasama dalam kelompok, tolong menolong, dan menjaga diri sendiri dalam lingkungan keluarga dan teman sebaya, (16) menunjukkan kegemaran membaca dan menulis, dan (17) menujukkan keterampilan menyimak, berbicara, membaca, menulis dan berhitung.

Standar Kompetensi Kelompok Mata Pelajaran (SK-KMP) Agama dan Akhlak Mulia untuk SD/MI/SDLB/Paket A adalah (1) menjalankan ajaran agama yang dianut sesuai dengan tahap perkembangan anak, (2) menunjukkan sikap jujur dan adil, (3) mengenal keberagaman agama, budaya, suku, ras dan golongan sosial ekonomi di lingkungan sekitarnya, (4) berkomunikasi secara santun yang mencerminkan harkat dan martabatnya sebagai makhluk Tuhan, (5) menunjukkan kebiasaan hidup bersih, sehat, bugar, aman dan memanfaatkan waktu luang sesuai dengan tuntunan agamanya, dan (6) menunjukkan kecintaan dan kepedulian terhadap sesama manusia dan lingkungan sebagai makhluk ciptaan Tuhan.

Sedangkan Standar Kompetensi Lulusan Mata Pelajaran (SK-LMP) PAI ini di SD/MI adalah (1) menyebutkan, menghafal, membaca dan mengartikan surat-surat pendek dalam Al-Qur'an, mulai surat Al-Fatihah sampai surat AlAlaq; (2) mengenal dan meyakini aspek-aspek rukun iman dari rukun iman kepada Allah sampai iman kepada Qadha dan Qadar; (3) berprilaku terpuji dalam kehidupan sehari-hari serta menghindari prilaku tercela; (4) mengenal dan melaksanakan rukun Islam mulai dari bersuci (thaharah) sampai zakat serta mengetahui tata cara pelaksanaan ibadah haji; dan (5) menceritakan kisah nabinabi serta mengambil teladan dari kisah tersebut dan menceritakan kisah tokoh orang-orang tercela dalam kehidupan nabi.

Mata pelajaran Pendidikan Agama Islam (PAI) adalah mata pelajaran yang 
termasuk dalam SK-KMP Agama dan Akhlak Mulia. PAI di Sekolah Dasar bertujuan untuk membentuk peserta didik menjadi manusia yang beriman dan bertakwa kepada Tuhan Yang Maha Esa serta berakhlak mulia.Jika dilihat dari SKL-SP, SK-KMP Agama dan Akhlak Mulia dan SK-LMP PAI untuk tingkat SD di atas banyak sekali materi ajar yang menunjukkan kaitan erat antara mata pelajaran PAI dengan pemeliharaan kebersihan dan kesehatan. Hali ini perlu diintegrasikan oleh guru PAI baik dalam proses pembelajaran dan diaplikasikan dalam upaya pemelihara kebersihan dan kesehatan untuk menuju sekolah sehat.

\section{Program Pemeliharaan Kebersihan dan Kesehatan di Sekolah}

UKS yang dijalankan di sekolahsekolah, dengan sasaran utamanya anakanak sekolah dan lingkungannya. Usaha ini dijalankan dengan mulai dari Sekolah Dasar sampai sekolah lanjutan. Sekarang pelaksanaannya diutamakan di SD. Hal ini disebabkan karena SD merupakan komunitas yang sangat besar, rentan terhadap berbagai penyakit, dan merupak dasar dari pendidikan selanjutnya. Meskipun demikian bukan berarti mengabaikan pelaksanaan selanjutnya di sekolah-sekolah lanjutan. Di SD tidak ada mata pelajaran khusus tentang kesehatan. UKS diintegrasikan pada mata pelajaran lain yang relevan, khususnya pelajaran Pendidikan Jasmani, termasuk juga PAI dan IPA.

Sekolah sebagai lembaga (institusi) pendidikan merupakan media yang sangat penting untuk menyalurkan segala bentuk pembaruan tata-cara dan kebiasaan hidup sehat, agar lebih mudah tertanam pada anak-anak. Dengan demikian, akan dapat memberikan pengaruh terhadap kehidupan keluarga, masyarakat sekitarnya, bahkan masyarakat yang lebih luas lagi. Setidak-tidaknya, secara indiviual, anak didik sebagai orang dewasa di kemudian hari akan memiliki sikap dan kebiasaan hidup dengan norma-norma kesehatan.

Pendidikan kesehatan di SD melalui program UKS, sangat efektif, sebab:

1. SD sebagai masyarakat sekolah, mempunyai komunitas peserta didik yang sangat besar;

2. SD sebagai lembaga pendidikan, tersebar luas di seluruh pelosok tanah air dari pedesaan hingga kota-kota besar;

3. Anak-anak seusia SD pada umumnya sangat peka terhadap perubahan dan pembaharuan. Bahkan, anak-anak memiliki sifat selalu ingin menyampaikan apa yang diterima dan diperolehnya kepada orang lain.

4. Dipandang dari segi pembiayaan pemerintah dan harapan untuk masa depan, pelaksanaan UKS di SD adalah ekonomis. Apalagi untuk kepentingan ini masyarakat (orang tua murid) selalu dapat dilibatkan dalam berbagai bentuk melaui Komite Sekolah.

Secara khusus, UKS bertujuan untuk mencapai keadaan kesehatan anakanak sekolah dan lingkungannya, sehingga dapat memberi desempatan kepada anak untuk tumbuh dan berkembang secara harmonis, serta belajar secara efisien dan optimal. Dengan demikian, melalui UKS diharapkan: (1) anak dapat tumbuh dan berkembang sesuai dengan tingkat usianya; (2) anak tidak menderita suatu penyakit ataupun mepunyai kelainan; (3) anak dapat mengikuti kegiatan pembelajaran dengan sebaik-baiknya; (4) anak mempunyai sikap, perilaku, dan kebiasaan hidup sesuai dengan norma-norma kesehatan; dan (5) anak-anak diharapkan dapat menyebarluaskan perilaku hidup sehat di lingkungan masyarakat yang lebih luas. 


\section{Hubungan Materi Pelajaran PAI dengan Kebersihan dan Kesehatan}

Sebetulnya masalah pemeliharaan kebersihan dan kesehatan ini sangat erat kaitannya dengan pemeliharaan terhadap lingkungan. Bukankah setiap hari kita sholat, dan sebelum sholat kita harus berwudhu dulu, ini menunjukkan bahwa Islam sangat memperhatikan masalah kebersihan. Jika sudah bersih diri maka akan diperoleh kesehatan rohani dan jasmani. Kesehatan jasmani dan rohani hanya akan terwujud sepenuhnya jika lingkungan yang ada disekitar kita selalu dipelihara dan dijaga dari berbagai kotoran, kerusakan dan lain-lain (Milya Sari, 2005).

Kesehatan tidak akan tercapai jika kita tidak bisa menjaga kebersihan. Banyak sekali ajaran agama Islam yang berhubungan dengan dua hal ini, baik yang dijelaskan secara eksplisit maupun implisit. Begitu pun pada Standar Kompetensi Kelompok Mata Pelajaran (SKKMP) untuk kelompok agama dan akhlak mulia pada tingkat SD/MI/SDLB/Paket A mengharapkan peserta didiknya bisa menjaga kebersihan, kesehatan, ketahanan dan kebugaran jasmaninya dalam kehidupan sesuai dengan tuntutan agama.

Dalam pelajaran PAI yang diajarkan di sekolah jika kita jeli melihatnya ternyata banyak yang berhubungan dengan masalah kebersihan dan kesehatan. Sebagai contoh hikmah yang terkandung dalam ibadah sholat dan puasa, disamping itu juga dari aspek halalharam makanan dan minuman yang kita makan. Kesemuanya itu jika benar-benar diterapkan dalam kehidupan sehari-hari menjadi suatu kebiasaan yang baik akan berdampak sangat besar dalam kehidupan bermasyarakat. Semua hal yang dijelaskan berikut ini disarikan dari buku: Mukjizat Ilmiah dalam Al-Quran oleh M. Kamil Abdushshamad (2002), Islam Agama Ramah Lingkungan oleh Yususf al-Qaradhawi (2002), Majalah
Ummi edisi spesial (November, 2002), dan ringkasan Ihya Ulumuddin oleh Imam Al Ghazali (1995).

\section{Peranan Guru PAI dalam Program Pemeliharaan Kebersihan dan Kesehatan di Sekolah}

Sehubungan dengan fungsi guru sebagai "pengajar", "pendidik", dan "pembimbing", maka diperlukan adanya berbagai peranan pada diri guru. Peranan guru ini akan senantiasa menggambarkan pola tingkah laku yang diharapkan dalam berbagai interaksinya, baik dengan siswa, sesama guru, maupun dengan staf yang lainnya. Dewasa ini guru berkembang sesuai dengan fungsinya yaitu membina untuk mencapai tujuan pendidikan. Lebih-lebih dalam sistem sekolah sekarang ini, masalah pengetahuan, kecakapan, dan keterampilan tenaga perlu mendapat perhatian yang serius. Bagaimanapun baiknya kurikulum, administrasi dan fasilitas, kalau tidak diimbangi dengan peningkatan kualitas guru-gurunya tidak akan membawa hasil yang diharapkan. Keberhasilan guru melaksanakan peranannya dalam bidang pendidikan sebagian besar teletak pada kemampuannya melaksanakan berbagai peranan yang bersifat khusus dalam situasi pembelajaran.

Berbagai studi literatur, ada banyak peranan yang harus dimiliki oleh seorang guru termasuk guru PAI sejalan dengan kompetensi yang harus dimilikinya. Adam \& Dickey dalam Oemar Hamalik (2004:48,49) mengemukakan 13 macam peranan guru dalam pembelajaran, yaitu guru sebagai pengajar, pemimpin kelas, pembimbing, pengatur lingkungan, partisipan, ekspeditur, perencana, supervisor, motivator, penanya, pengganjar (pemberi penghargaan), evaluator, dan konselor. Sardiman A.M. (2001) merinci peranan guru tersebut dalam pembelajaran, yaitu guru sebagai informator, organisator, pengarah/- 
direktor, inisiator, transmitter, fasilitator, mediator, dan evaluator.

Slameto (2003) mengemukakan bahwa peranan guru telah meningkat dari sebagai pengajar menjadi sebagai direktur pengarah belajar. Sebagai direktur belajar, tugas dan tanggung jawab justru menjadi lebih meningkat. Banyak fungsi guru yang melekat di dalamnya, yaitu sebagai perencana program, pengelola pengajaran, penilai hasil belajar, motivator belajar dan sebagai pembimbing.

Khusus sebagai pembimbing dalam pembelajaran, guru diharapkan mampu untuk: (1). Mengenal dan memahami setiap siswa baik secara individu maupun kelompok; (2). Memberikan penerangan kepada siswa mengenai hal-hal yang diperlukan dalam proses belajar; (3). Memberikan kesempatan yang memadai agar setiap siswa dapat sesuai dengan kemampuan pribadinya; (4). Membantu setiap siswa dalam mengatasi masalah-masalah pribadi yang dihadapinya; dan (5). Menilai keberhasilan setiap langkah kegiatan yang telah dilakukannya.

Pendidikan agama Islam di sekolah dari tingkat dasar hingga perguruan tinggi selalu membahas tentang ajaran Islam yang berkaitan dengan hidup sehat, karena memang salah satu tujuan PAI adalah pembiasaan hidup sehat. Konsepsi agama tentang hidup sehat telah diajarkan nabi sejak mulai diturunkannya agama Islam di muka bumi kepada manusia. Ajaran-ajaran agama tentang mandi, wudhu, dan bersuci setelah buang air, serta syarat sah shalat harus bersih semua hal. Agar budaya hidup bersih dapat tertanam sejak dini pada setiap individu muslim melalui bangku pendidikan sejak dini merupakan tugas berat guru PAI.

A. Qodri A. (2004) menjelaskan bahwa secara filosofis, PAI bertujuan untuk membentuk al-insan al-kamil atau manusia paripurna. Beranjak dari konsep ini, setidaknya PAI diarahkan pada dua dimensi, yaitu: dimensi dialektika horizontal terhadap sesama dan dimensi ketundukan vertikal kepada Allah. Oleh karena itu, tujuan PAI sesungguhnya lebih berorientasi pada transinternalisasi ilmu kepada peserta didik agar mereka menjadi insan yang berkualitas, baik dalam aspek keagamaan maupun sosial. Dalam arti lain, tujuan PAI yang dibangunnya bukan hanya bersifat internal bagi peserta didik guna memiliki sejumlah ilmu pengetahuan dan mengenal Khaliqnya, akan tetapi juga secara eksternal mampu hidup dan merefleksikan ilmu yang dimilikinya bagi kemakmuran alam semesta. Untuk mencapai tujuan ideal ini, maka PAI hendaknya diformulasikan secara sistematik dan integral, sehingga dapat merangsang tumbuhnya dinamika fitrah peserta didik secara optimal.

Konsep PAI yang ideal adalah mengharmonisasikan sisi IPTEK dan IMTAQ. Dengan pendekatan yang harmoni tersebut, diharapkan akan terwujudnya sosok peserta didik yang memilki kepribadian integral (jasmani dan rohani), serta menguasai ilmu Islam dan ilmu umum secara proporsional. Sehingga konsep-konsep agama diaplikasikan secara sempurna dalam kehidupan sehari-hari secara gradual, tidak terkecuali dengan budaya hidup bersih dan menjaga kesehatan.

Berkaitan dengan program UKS, peranan guru PAI dalam mensukseskan program ini sangat besar sekali, karena aspek-aspek yang ditetapkan dalam program UKS sangat erat kaitannya dengan pokok-pokok ajaran Islam. Guru PAI di samping melaksanakan tugas pengajaran, juga melaksanakan tugas pendidikan dan pembinaan bagi peserta didiknya, membantu pembentukan kepribadian, pembinaan akhlak, disamping menumbuhkan dan mengembangkan keimanan. Seluruh penampilan pribadinya dan tingkah lakunya hendaknya men- 
cerminkan nilai-nilai Islam yang dihayatinya, misalnya dalam bertutur kata, sikap, cara berpikir, dan perilaku dalam pergaulan, semua itu tercermin dalam kehidupan sehari-harinya.

Salah satu tugas penting guru PAI adalah pembinaan akhlak. Membiasakan anak memperhatikan lingkungannya, menjaga kebersihan dan kesehatan diri semua itu butuh pembiasaan. Pembiasaan dan pengulangan perbuatan yang baik tersebut akan menjadi keharusan moral dan perbuatan akhlak terpuji, kebiasaan yang mendalam, yang tumbuh dan berkembang secara wajar dalam diri peserta didiknya.

\section{METODOLOGI PENELITIAN}

Penelitian ini bertujuan untuk mengidentifikasi peranan guru PAI sebagai pendidik dalam mengintegrasikan materi ajar PAI dengan pendidikan kesehatan di SDN 23 Sungai tarab, juga mendeteksi partisipasi guru PAI dalam melaksanakan pelayanan kesehatan dan pembinaan lingkungan sekolah sehat. Sumber data yang digunakan adalah guru PAI, guru-guru bidang studi lainnya, siswa kelas 6 tahun pelajaran 2007/2008 yang berjumlah 49 orang, kepala sekolah, wakil kepala sekolah dan petugas kebersihan serta pihak-pihak lain yang terkait dengan masalah kebersihan dan kesehatan.

Semua substansi dalam tujuan penelitian dirinci dalam instrumen penelitian. Dan dari rincian tersebut, sesuai dengan sifat datanya, disusun dua jenis instrumen, yaitu instrumen untuk data kuantitatif dan instrumen untuk data kualitatif. Instrumen ditetapkan melalui hasil observasi ke SDN 23 Sungai tarab, diskusi dan pengkajian literatur serta pengalaman. Dengan cara ini dihasilkan rincian tentang komponen instrumen tersebut berupa sub-komponen Pelaksanaan UKS di SDN 23 Sungai tarab sehingga dapat dijadikan sebagai kisikisi instrumen.

Pengumpulan data kuantitatif berasal dari angket yang disebarkan kepada siswa untuk mengetahui ada tidaknya peranan guru PAI dalam usaha pemeliharaan kebersihan dan kesehatan di SDN 23 Sungai tarab. Jenis angket yang digunakan adalah tertutup. Pengumpulan data kualitatif diselenggarakan dengan mewawancarai guru PAI, guru bidang studi lainnya, kepala sekolah beserta wakilnya dan petugas kebersihan dengan menggunakan pedoman wawancara/ pengamatan yang telah dipersiapkan. Hasil wawancara dan pengamatan dicatat dan disusun sebagai data dasar yang pada tahap berikutya diolah dan ditafsirkan.

Teknik analisis data untuk angket yang digunakan adalah analisis deskriptif kuantitatif dengan teknik prosentase (\%), serta ditunjang oleh analisis kualitatif dari hasil wawancara kepada guru dan kepala sekolah. Data kuantitatif dan kualitatif yang diperoleh dikaitkan satu sama lain untuk memperoleh gambaran yang lebih menyeluruh tentang kondisi riil peranan guru PAI dalam usaha pemeliharaan kebersihan dan kesehatan di SDN 23 Sungai tarab. Dari gambaran ini dapat ditarik kesimpulan tentang arah kondisi yang perlu dikembangkan untuk meningkatkan mutu guru dan pembelajaran PAI di sekolah.

\section{TEMUAN PENELITIAN}

\section{Peranan Guru PAI sebagai Pendidik dalam Mengintegrasikan Materi Ajar PAI dengan Pendidikan Kesehatan}

Peranan guru PAI dalam mengintegrasikan materi PAI dengan Program kebersihan dan kesehatan di SD Sungaitarab dapat diungkapkan setelah melakukan mewawancara dengan guru PAI tersebut. Peneliti telah melakukan wawancara dengan dua orang guru PAI, yaitu 
Bapak SY. Dt. Paduko Mamin, S.Ag (selanjutnya disingkat G1) dan Ibuk Rahmawati, A.Ma. (G2) termasuk juga dengan kepala sekolah Amrizal Siry, S.Ag (KS), dan wakil kepala sekolah (WK). Hasil wawancara menunjukkan bahwa guru PAI di sekolah ini telah dapat mengintegrasikan materi PAI tersebut dengan 5 (lima) bentuk Kegiatan Kerja UKS yang dilaksanakan di sekolah. Peneliti telah menanyakan masalah ini kepada G1 dengan pertanyaan sebagai berikut: Bagaimana Bapak mengintegrasikan materi ajar PAI dengan pendidikan kesehatan? G1 mengemukakan bahwa:

"Integrasi materi PAI dengan Program kebersihan dan kesehatan di sekolah ini melalui materi thaharah. Dalam thaharah diajarkan kebersihan dan kesucian, adanya macam-macam air untuk bersuci diantaranya air mutlak /air mustakmal, yaitu air yang tujuh. Air yang bersih dan suci itu akan memberikan kesehatan. Dalam solat syaratnya juga harus suci pakaian, tempat dan badan. Tempat yang suci itu berarti bersih, kalau tempat solatnya bersih berarti sudah mencerminkan salah satu dari kebersihan lingkungan sekolah" (G1).

Integrasi materi ajar thoharah yang dikemukan G1 di atas sangat bermanfaat dalam menciptakan kebersihan lingkungan sekolah. Siswa akan memiliki konsep dan pemahaman bahwa membiasakan diri selalu bersih (thoharoh) sebelum dan setelah sholat akan membawa manfaat yang baik terhadap diri dan lingkungan. Siswa akan selalu membiasakan diri mereka tidak membuang sampah di sembarangan tempat. Mereka akan menjaga kebersihan badan dan pakaiannya kapan saja, tidak hanya akan pergi sekolah. Dengan demikian solat yang mereka kerjakan membawa banyak hikmah dalam keseharian mereka, termasuk membiasakan hidup bersih.
Di bagian lain peneliti menanyakan kepada G2, bagaimana usaha guru PAI memadukan materi PAI dalam upaya pembinaan sekolah sehat. Guru G2 mengemukakan komentarnya:

"Dalam usaha pembinaan se-kolah sehat, melalui pelajaran PAI juga diajarkan pada anak bahwa dalam sebuah hadis dijelaskan Allah itu bersih dan menyukai kebersihan, dan juga hadis yang menjelaskan kebersihan itu sebagian dari iman. Berarti jika kita menjalankan perintah Allah dan anjuran hadis itu itu artinya kita dicintai Allah. Jadi usaha yang kita lakukan dalam pemeliharaan kebersihan dan kesehatan itu sangat disukai dan diredhai Allah" (G2).

Berdasarkan jawaban guru G2 di atas dapat dikemukakan bahwa guru PAI di SD 25 Sungai tarab telah berupaya melakukan pembinaan sekolah sehat melalui pelajaran PAI yang diajarkannya. Upaya sekolah sehat tidak hanya dilaksanakan melalui penyuluhan-penyuluhan oleh petugas dari dinas kesehatan atau Puskesmas setempat, tetapi juga melalui materi pelajaran yang relevan. Hal ini sesuai juga yang dikemukakan oleh Kepala SD (KS) tersebut seperti berikut ini:

"Pada KTSP sekarang ada pelajaran tematik yang mengintegrasikan banyak mata pelajaran dalam satu topik bahasan. Materi pelajaran Agama, PP$\mathrm{KN}$, dan IPA digabungkan dalam satu tema tertentu yang saling berkaitan. Misalnya Agama mengajarkan kebersihan, kemudian dalam IPA diajarkan kebersihan lingkungan termasuk kebersihan air, begitu juga dengan PKN" (KS).

Untuk mendukung pelaksanaan sekolah sehat, pelajaran tematik yang dikemukakan oleh KS di atas sangat perlu dilakukan, karena di SD tidak ada mata pelajaran khusus tentang kesehatan. UKS diintegrasikan pada mata pelajaran lain yang relevan. Jika diperhatikan betul 
Permendiknas RI No. 22 Tahun 2006, ternyata SK-KMP Agama dan Akhlak Mulia untuk SD/MI/SDLB/Paket A jelas-jelas dinyatakan bahwa kebiasaan hidup bersih dan sehat itu termasuk salah satu SK-KMP yang perlu dicapai oleh Guru PAI dalam proses pembelajarannya. Lengkapnya SK-KMP tersebut sebagai berikut (1) menjalankan ajaran agama yang dianut sesuai dengan tahap perkembangan anak, (2) menunjukkan sikap jujur dan adil, (3) mengenal keberagaman agama, budaya, suku, ras dan golongan sosial ekonomi di lingkungan sekitarnya, (4) berkomunikasi secara santun yang mencerminkan harkat dan martabatnya sebagai makhluk Tuhan, (5) menunjukkan kebiasaan hidup bersih, sehat, bugar, aman dan memanfaatkan waktu luang sesuai dengan tuntunan agamanya, dan (6) menunjukkan kecintaan dan kepedulian terhadap sesama manusia dan lingkungan sebagai makhluk ciptaan Tuhan.

Dengan demikian pemeliharaan dan pembiasaan hidup bersih dan sehat peserta didik di sekolah tidak hanya menjadi tanggung jawab guru Pendidikan Jasmani, Olahraga dan Kesehatan tetapi juga merupakan tanggung jawab guru PAI baik dalam proses pembelajaran maupun di luar pembelajaran. Materi Toharah dalam matapelajaran PAI hendaknya bagi guru PAI betulbetul dikemas dengan proses pembelajaran menarik baik dari aspek teoritis dan praktis. Untuk tercapainya pelajaran tematik seperti yang dikemukakan KS tersebut di atas, maka perlu antara guru PAI, guru IPA dan Guru PKN koordinasi yang baik dalam menentukan strategis proses pembelajarannya.

Pembelajaran tematik ini sangat cocok sekali diterapkan dalam program pendidikan dewasa ini, apalagi dalam mendukung berbagai kegiatan dalam program UKS. Melihat manfaatnya, Program UKS ini sudah seharusnya mendapat tempat dan perhatian yang sungguh-sungguh dari Pemerintah pusat dan daerah. Memelihara kebugaran jasmani dan perilaku hidup sehat, menjadi hal yang penting dalam usaha meningkatkan mutu pendidikan. Karena jika siswanya sehat yang didukung oleh lingkungan sekolah yang sehat maka prestasi belajar siswa juga akan meningkat.

Lingkungan sekolah yang sehat akan mempengaruhi prestasi siswanya. Siswa akan bersemangat belajar jika lingkungan beralajarnya nyaman dan sehat. Prestasi akademik yang dicapai SDN 23 Sungai tarab adalah rata-rata NEM yang selalu di atas 8. Setiap tahun siswanya lulus $100 \%$ serta dapat melanjutkan ke SMP/MTsN 100\% pula. Prestasi dalam Lomba Sekolah Sehat, SDN 23 Sungai tarab tahun 2006 di tingkat kabupaten berhasil sebagai juara satu dan tahun 2007 di tingkat provinsi berhasil pula sebagai juara satu. Sejalan dengan ini, R.J. Soenarjo (2002:2) mengemukakan bahwa untuk mencapai mutu pendidikan yang tinggi diperlukan kehidupan yang sehat, cerdas, demokratis, dan mampu bersaing sehingga dapat meningkatkan kesejahteraan semua warga negara Indonesia.

\section{Partisipasi Guru PAI dalam Me- laksanakan Pelayanan Kesehatan}

Berdasarkan komponen dan sub komponen Pelaksanaan UKS di SDN 23 Sungai tarab ada 3 (tiga) ruang lingkup UKS yang diselenggarakan di sekolah ini yaitu; (a). Penyelenggaraan Pendidikan Kesehatan, (b). Penyelenggaraan Pelayanan Kesehatan, dan (c). Menciptakan Lingkungan Kehidupan Sekolah Sehat. Ketiga ruang lingkup UKS ini di bagi dalam 5 (lima) bentuk Kegiatan Kerja UKS yaitu, (1). Menciptakan Lingkungan Kehidupan Sekolah Sehat, (2). Pemeliharaan Kebersihan Lingkungan, (3). Pemeliharaan Kebersihan perorangan, (4). Pendidikan Kesehatan, dan (5). Pelayanan Kesehatan. 
Partisipasi guru PAI dalam melaksanakan pelayanan kesehatan di SDN 23 Sungai tarab dapat dilihat pada Bentuk Kegiatan Kerja UKS nomor 1, 2 dan 3. kesemuanya itu terangkum dalam Tabel 1. Seberapa besar partisipasi guru PAI dalam melaksanakan pelayanan kesehatan di SDN 23 Sungai tarab diketahui dengan cara menyebarkan angket kepada siswa kelas 6 yang berjumlah 49 orang. Bagaimana pendapat siswa terhadap partisipasi guru PAI mereka terhadap pelayanan kesehatan di sekolah mereka?.

Dari hasil penyebaran angket kepada siswa kelas enam terlihat bagaimana partisipasi guru PAI dalam melaksanakan pelayanan kesehatan di SDN 23 Sungai tarab. Sebagian besar siswa menyatakan guru PAI mereka termasuk sering berpartisipasi dalam berbagai kegiatan pelayanan kesehatan di sekolahnya. Dari 49 siswa tersebut, ratarata lebih dari setengahnya $(50 \%)$ menyatakan guru PAI terlibat atau berpartisipasi dalam seluruh program pelayanan kesehatan di sekolah. Dari 24 jenis kegiatan pelayanan kesehatan yang diselenggarakan di sekolah hanya sedikit saja guru PAI yang tidak begitu terlibat, seperti item No. 14 (mengikuti kegiatan sanggar kesenian), item no. 16 (memeriksa kesehatan rambut), dan item No. 18 (memeriksa kesehatan telinga) jawaban siswa yang tidak sampai setengahnya $(50 \%)$.

Ini menunjukkan guru PAI di SDN 23 Sungai tarab ikut berpartisipasi dalam setiap program pelayanan kesehatan yang dilaksanakan di sekolah. Hal ini juga diperkuat dengan hasil wawancara yang dilakukan kepada guru PAI di sekolah tersebut. Hasil wawancara dengan guru PAI di sekolah ini menyatakan bahwa mereka sering memberikan nasehat tentang pentingnya menjaga kebersihan dan kesehatan diri siswanya. Nasehat tentang pentingnya menjaga kebersihan dan kesehatan kepada siswa selalu disampaikan dalam upacara agama setiap Jum'at pagi. Selain itu, setiap pagi sebelum belajar harus diperiksa kebersihan kelas, kuku, pakaian dan kebersihan badan. Kemudian dalam usaha bersama antara personil sekolah diadakan kegiatan sikat gigi masal 1 X 2 minggu. Dalam keseharian, siswa selalu diingatkan dan dinasehati untuk selalu membuang sampah pada tempatnya.

Peranan yang dimainkan guru PAI ini sangat membantu untuk membiasakan siswa hidup bersih. Artinya materi yang diajarkan PAI juga ikut mendukung pembiasaan siswa hidup bersih. Hal ini sangat sesuai dengan Surat Keputusan Bersama 4 Menteri (Mendiknas, Menkes, Menag, dan Mendagri) Nomor: 1/U/SKB/2003 tentang UKS Pasal 2 yang menyatakan bahwa: "Usaha Kesehatan Sekolah (UKS) adalah untuk meningkatkan mutu pendidikan dan prestasi belajar peserta didik dengan meningkatkan prilaku hidup bersih dan sehat dan derajat kesehatan peserta didik maupun warga belajar serta menciptakan lingkungan yang sehat, sehingga memungkinkan pertumbuhan dan perkembangan yang harmonis dan optimal dalam rangka pembentukan manusia Indonesia seutuhnya".

Seberapa sering guru PAI berpartisipasi dalam setiap kegiatan UKS di SDN 23 Sungai tarab juga bisa dilihat dengan membandingkan persentase partisipasinya dengan guru lain. Hal ini dapat dilihat pada Tabel 2 berikut ini.

Tabel 2: Persentase tingkat partisipasi kepala sekolah dan guru dalam mengajak siswa untuk menjaga kebersihan dan kesehatan diri di lingkungan sekolah

\begin{tabular}{|c|c|c|c|}
\hline $\begin{array}{l}\mathbf{N} \\
\mathbf{0}\end{array}$ & Unsur & $\Sigma$ & $\%$ \\
\hline 1 & Kepala Sekolah & 14 & 16 \\
\hline 2 & Guru PAI & 11 & 13 \\
\hline 3 & Guru Kelas/ wali & 39 & 46 \\
\hline
\end{tabular}




\begin{tabular}{|c|l|c|c|}
\hline & kelas & & \\
\hline 4 & Guru Penjaskes & 11 & 13 \\
\hline 5 & $\begin{array}{l}\text { Guru Bahasa } \\
\text { Inggris }\end{array}$ & 9 & 11 \\
\hline
\end{tabular}

Dari tabel 2 di atas terlihat bahwa guru yang paling tinggi partisipasinya dalam kegiatan UKS adalah guru kelas/wali kelas 46\%. Jika dibandingkan dengan persentase guru PAI yang hanya $13 \%$ (sama dengan guru Penjaskes dan bahasa Inggris), angkanya memang tidak begitu besar. Hal ini jelas dipahami jika dilihat dari intensitas pertemuan guru PAI dengan siswa hanya pada jam-jam pelajaran agama saja atau waktu kegiatan-kegiatan tertentu, berbeda dengan guru kelas yang bertemu setiap hari dengan siswanya. Jadi wajarlah jika persentasenya pertisipasinya tidak setinggi guru kelas. Namun demikian melihat jawaban siswa pada tabel 2 di atas terlihat guru PAI ikut terlibat dalam berbagai kegiatan UKS di lingkungan sekolah. Salah satu cara yang dapat dilakukan untuk memberdayakan program UKS di SD adalah mengembangkan MBS. Indra Djati Sidi, Dirjen Pendidikan Dasar dan Menengah Depdiknas selaku Ketua TP UKS Pusat mengemukakan bahwa model MBS ini lebih banyak memberikan otonomi yang lebih besar kepada sekolah. Sekolah memiliki kewenangan yang lebih besar dalam mengelola sekolahnya sehingga sekolah lebih mandiri. Dengan kemandiriannya, sekolah lebih berdaya dalam mengembangkan berbagai program, termasuk program UKS (2004:4-5).

MBS memberikan kewenangan kepada sekolah (kepala sekolah) melakukan pengambilan keputusan secara partisipatif. Indra Djati Sidi (2004:8) juga mengemukakan bahwa ada kebijakankebijakan yang dapat diambil oleh sekolah yang berkaitan dengan pengembangan pendidikan kesehatan dan penanaman prilaku hidup sehat di sekolah, antara lain: (1) melaksanakan pendidikan kesehatan secara kurikuler dan ekstra kurikuler, (2) menerapkan sekolah sebagai kawasan bebas asap rokok, (3) menekankan pentingnya perilaku sehat. (4) mengupayakan lingkungan sekolah yang sehat, yaitu lingkungan yang kondusif dan terwujudnya keadaan sehat, bebas polusi, tersedia air bersih dan perindangan sekolah yang memadai, dan (5) mengembangkan life skill education pada setiap jenis dan jenjang pendidikan.

\section{Peranan Guru PAI sebagai Pem- bimbing dalam Pembinaan Lingkung- an Sekolah Sehat}

Peran guru PAI dalam melaksanakan pelayanan kesehatan di SDN 23 Sungai tarab dapat dilihat pada Bentuk Kegiatan Kerja UKS nomor 4 dan 5, kesemuanya itu terangkum dalam Tabel 10. Selain mengajarkan materi Agama Islam di kelas, dalam Kegiatan Kerja UKS di sekolah ini guru PAI juga dituntut untuk memberikan pendidikan tentang kesehatan dan melaksanakan pelayanan kesehatan kepada siswa-siswanya.

Dari hasil wawancara penulis dengan siswa SDN 23 Sungai tarab tentang peran guru PAI sebagai pembimbing dalam pembinaan lingkungan sekolah sehat, terlihat hampir sebagian besar siswa menyatakan guru PAI mereka berperan sebagai pembimbing dalam pembinaan lingkungan sekolah sehat di SDN 23 Sungai tarab. Dari 10 kegiatan yang dilaksanakan di sekolah dalam rangka pembinaan sekolah sehat, sebagian besar siswa (lebih dari 50\%) menyatakan semua guru PAI sering berpartisipasi dalam semua kegiatan ini. Jika melihat besarnya partisipasi guru PAI dengan guru lainnya pada tabel 9 terlihat bahwa semua guru di sekolah ini terlibat dalam menyukseskan program sekolah sehat. Ini berarti ada kesadaran dari semua guru bahwa usaha kesehatan sekolah merupakan tugas dan tanggung jawab 
bersama seluruh personil/guru di SD 23 Sungai tarab. Sehingga semua pihak ikut berpartisipasi untuk menyukseskannya.

Peran guru PAI di atas perlu ditingkatkan lagi adalah bagaimana mengusahakan pendidikan agama Islam tersebut dapat berhubungan lansung dengan pembentukan prilaku sehari peserta didik. A. Qodry Azizy (2002: 142) menyarankan bahwa pendidikan agama tidak cukup hanya menghafal ajaranajaran atau teori-teori. Misalnya ada Hadis: "kebersihan adalah bagian dari iman", tidak cukup ditulis dan dihafal oleh siswa kemudian ditagih melalui ujian tertulis. Lalu, jika anak biasa menulis dan menghafal hadis tersebut, ia akan memperoleh nilai sepuluh. Makna kebersihan harus diwujudkan dalam keseharian. Apakah siswa telah betul-betul rapi, betul-betul menerapkan pola hidup bersih? Apakah lingkungan sekolah sudah mencerminkan kebersihan? Dan sebagainya. Beberapa pertanyaan tersebut yang berkaitan dengan siswa oleh guru PAI hendaknya menjadi aspek yang perlu dinilai untuk siswa sebagai ukuran keberhasilan pendidikan agama Islam.

\section{Keterbatasan Penelitian}

Berdasarkan temuan penelitian dan pembahasannya, penelitian ini mempunyai beberapa keterbatasan, antara lain:

1. Penelitian ini hanya dilakukan di SDN yang telah berhasil sebagai juara 1 Lomba Sekolah Sehat tingkat Provinsi Sumatera Barat tahun 2007. Perlu juga dilakukan penelitian di sekolah yang tidak mendapatkan juara atau tidak ikut lomba baik tingkat SD, SMP maupun SMA. Untuk menghasilkan gambaran yang sebenarnya tentang kondisi riil peranan guru PAI dalam mewujudkan sekolah sehat. Jika penelitian ini dilaksanakan di tiga lokasi tersebut tentu memerlukan dana yang lebih besar lagi dan alokasi waktu yang cukup.

2. Penelitian ini hanya dilakukan di sekolah belum di madrasah. Oleh sebab itu, penelitian ini perlu dilanjutkan dengan penelitian berikutnya di madrasah (MI, MTs \& MA) sehingga akan nampak hasil perbandingan bagaimana peranan guru PAI di sekolah dan madrasah. Kedua rekomendasi penelitian tersebut akan sangat bermanfaat bagi pihak terkait (Depag RI) dalam mengambil kebijakan selanjutnya.

\section{KESIMPULAN DAN REKOMEN- DASI}

\section{Kesimpulan Penelitian}

Guru PAI SDN 23 Sungai tarab yang berperan sebagai pendidik dan pembimbing telah dapat mengintegrasikan materi PAI dengan program kebersihan dan kesehatan di SD tersebut. Integrasi yang dilaksanakan guru PAI tersebut lebih banyak dilaksanakan melalui materi pelajaran thaharah. Di samping itu guru PAI juga ikut berpartisipasi dalam setiap program pelayanan kesehatan yang dilaksanakan di sekolah itu. Walaupun persentasenya partisipasi guru PAI tidak setinggi guru kelas, namun guru PAI tetap aktif dalam berbagai kegiatan UKS di lingkungan sekolah.

\section{Rekomendasi}

Hasil penelitian ini dapat menjadi bahan pertimbangan / rekomendasi / saran-saran kepada berbagai pihak terutama:

1. Guru PAI SDN 23 Sungai tarab untuk terus meningkatkan peranannya dalam upaya mengintegrasikan materi ajar PAI tersebut dengan berbagai aspek praktis yang dapat diterapkan oleh peserta didik dalam kehidupan 
sehari-hari, tidak hanya upaya pemeliharaan hidup bersih dan sehat baik di sekolah maupun di rumah.

2. Kepala Sekolah SD 23 Sungai tarab diharapkan selalu membimbing semua guru untuk dapat menjadikan predikat terbaik dalam Lomba Sekolah Sehat tingkat Provinsi tersebut sebagai motivasi dalam mempertahankan sekolah bersih dan sehat.

3. Pimpinan PTAI dan staf dosennya di Sumbar sebagai lembaga pendidikan LPTK dan tenaga pengajar yang mendidik calon guru PAI untuk dapat mengembangkan silabus dan materi perkuliahan yang dapat membentuk calon guru PAI yang profesional. Guru PAI yang profesional akan punya kompetensi dalam mengembangkan materi ajar yang dapat diamalkan/diaplikasikan oleh peserta didiknya dalam kehidupan seharihari.

4. Depag RI sebagai instansi yang berwenang dalam upaya strategis pengambilan kebijakan untuk meningkat-

\section{DAFTAR RUJUKAN}

A. Qodry Azizy. 2002. Pendidikan (Agama) untuk Membangun Etika Sosial (Mendidik Anak Sukses Masa Depan: Pandai dan Bermanfaat). Semarang: Aneka Cipta.

----. 2004. Pendidikan Agama dan Pembiasaan Hidup Sehat. Solo: Tim Pembina UKS Pusat.

Ekspose Kepala SDN 23 Sungai tarab. 2006. Pelaksanaan Sekolah Se-hat di SDN 23 Sungai tarab Kec. Sungai tarab. Kab. Tanah Datar Sumbar.

Imam Al Ghazali. 1995. Ringkasan Ihya Ulumuddin. Jakarta: Pustaka Amani.

Indra Djati Sidi. 2004. Kebijakan Depdiknas dalam Pembinaan dan kan kemampuan professional guru PAI dan peranannya dalam pemeliharaan kebersihan dan kesehatan baik di sekolah maupun di madrasah. Khusus di madrasah, masalah pemeliharaan kebersihan dan kesehatan sangat memerlukan perhatian oleh segenap civitas madrasah (guru, kepala madrasah, siswa), pengawas dan Depag karena banyak madrasah yang terlihat kumuh, kotor dan tidak memenuhi standar madrasah sehat

5. Puslitbang Pendidikan Agama dan Keagamaan Depag RI sebagai penyandang dana penelitian ini diharapkan dapat memberikan bantuan dana penelitian selanjutnya, karena penelitian ini dirasa perlu dilanjutkan ke tahap berikutnya yaitu bagaimana pula peranan guru madrasah dalam mewujudkan madrasah sehat dan bersih. Justru di madrasah sendiri yang terlihat masalah kebersihan dan kesehatan ini sangat perlu mendapatkan perhatian yang serius oleh Depag RI.

Pengembangan UKS. Jakarta: Ditjen Dikdasmen Depdiknas RI.

Majalah Ummi (edisi spesial). November 2002. Hidup Sehat cara Nabi. Jakarta: PT. Kimus Bina Tadzkia.

Milya Sari. 2005. Peran Manusia terhadap Lingkungan dalam Perspektif Islam. (Batusangkar, Ta'dib, Jurnal Ilmu Pendidikan, Vol, 2 . Desember 2005). Hal. 60-68.

M. Kamil Abdushshamad. 2002. Mukjizat Ilmiah dalam Al-Quran. Jakarta: Akbar media Eka Sarana.

Oemar Hamalik. 2004. Pendidikan Guru Berdasarkan Pendekatan Kompetensi. Jakarta: Bumi Aksara. 
Peraturan Menteri Pendidikan Nasional Nomor 22 tahun 2006. Standar Isi untuk Satuan Pendidikan Dasar dan Menengah. Jakarta: Setjen Diknas RI.

Peraturan Pemerintah RI No.19 Tahun 2005 tentang Standar Nasional Pendidikan. Jakarta: Sinar Grafika.

Proyek Penyuluhan Kesahatan Masyarakat. 1993. Pedoman Dasar Usaha Kesehatan Sekolah. Padang: Kanwil Depkes Propinsi Sumatera Barat.

R.J. Soenarjo. 2002. UKS Usaha Kesehatan Sekolah. Bandung: PT. Remaja Rosdakarya.

Sardiman A.M. 2001. Interaksi dan Motivasi Belajar Mengajar. Jakarta: RajaGrafindo Persada.

SKB Empat (4) Menteri. 2003. Mendiknas No.1/U/SKB/2003; Menkes
No. 1067/Menkes/SKB/VII/2003; Menag No. MA/130A/2003 dan Mendagri No.26/2003 tanggal 23 Juli 2003 tentang Pembinaan dan Pengembangan UKS .

Slameto. 2003. Belajar dan Faktorfaktor yang Mempengaruhinya. Jakarta: Rineka Cipta.

Tim Pembina UKS Pusat. 2004. Hasil Rapat Kerja Nasional Usaha Kesehatan Sekolah (Rakernas UKS ) VII. Solo: Tim Pembina UKS Pusat.

Yusuf Qaradhawi. 2002. Islam Agama Ramah Lingkungan. Jakarta: Pustaka Al-Kautsar.

Zakiyah Darajat. 1994. Pendidikan Islam dalam Keluarga dan Sekolah. Jakarta: Ruhama. 